\title{
Pyruvate Carboxylase and Phosphoenolpyruvate Carboxykinase Activity in Leukocytes and Fibroblasts from a Patient with Pyruvate Carboxylase Deficiency
}

\author{
BETH M. ATKIN, ${ }^{(4)}$ MERTON F. UTTER, AND MITCHELL B. WEINBERG \\ Division of Genetics and Department of Pediatrics, University of Oregon Health Sciences Center, Portland, Oregon; \\ and Department of Biochemistry, School of Medicine, Case Western Reserve University, Cleveland, Ohio, USA
}

\begin{abstract}
Summary
Normal values are given for the activities of pyruvate carboxylase (E.C. 6.4.1.1), mitochondrial phosphoenolpyruvate carboxykinase (E.C. 4.1.1.32, PEPCK), and citrate synthase (E.C. 4.1.3.7) in fibroblasts, lymphocytes, and leukocytes. Also given are values for these enzymes in the leukocytes and fibroblasts from a severely mentally and developmentally retarded patient with proximal renal tubular acidosis and hepatic, cerebral, and renal cortical pyruvate carboxylase deficiency. In normals, virtually all of the mitochondrial PEPCK and pyruvate carboxylase activity was present in the mononuclear leukocyte fraction of whole venous blood. Cellular fractionation studies with human lymphocytes and fibroblasts demonstrated that all of the PEPCK activity in these cells is mitochondrial. Normal values for pyruvate carboxylase in leukocytes were $0.092(0.070-0.208) \mathrm{mU} / \mathrm{mg}$ protein $(n=5)$, in lymphocytes $0.154(0.092-0.262) \mathrm{mU} / \mathrm{mg}$ protein $(n=5)$, and in fibroblasts $1.36(0.778-2.19) \mathrm{mU} / \mathrm{mg}$ protein $(n=5)$. The patient with hepatic, renal, and cerebral pyruvate carboxylase deficiency had no detectable activity $(<0.009 \mathrm{mU} / \mathrm{mg}$ protein) in his leukocytes and $0.018 \mathrm{mU} / \mathrm{mg}$ protein in his fibroblasts. Data from an assay for pyruvate carboxylase activity in the patient's fibroblasts show that the activity observed is significant but very close to the lower limits of the assay. Values for PEPCK in normal lymphocytes were $1.42(0.824-1.88) \mathrm{mU} / \mathrm{mg}$ protein $(n=5)$, in leukocytes 1.68 $(1.64-1.72) \mathrm{mU} / \mathrm{mg}$ protein $(n=2)$, and in fibroblasts 5.49 (3.94-6.33) $\mathrm{mU} / \mathrm{mg}$ protein $(n=6)$.
\end{abstract}

\section{Speculation}

The absence of pyruvate carboxylase in the lymphocytes and fibroblasts of a patient with hepatic, renal, and cerebral pyruvate carboxylase deficiency supports the hypothesis that only one form of pyruvate carboxylase exists in the human and suggests that the examination of lymphocytes or fibroblasts for pyruvate carboxylase activity may be a valid method for diagnosing this disease. Furthermore, our results suggest that family studies and prenatal diagnosis may be possible for pyruvate carboxylase deficiency.

Congenital lactic acidosis is a metabolic acidosis characterized by hyperlactatemia and is usually accompanied by hyperalaninemia and hyperpyruvatemia. The clinical course of the disease has ranged from severe acidosis and neonatal death (13) to mild intermittent lactic acidosis concomitant with normal physical and cerebral development (7). In contrast to acquired lactic acidosis, congenital lactic acidosis has been associated with a specific deficiency in one of several enzymes of pyruvate and glucose metabolism (Fig. 1): glucose-6-phosphatase (E.C. 3.1.3.9) (19, 23), fructose 1,6-bisphosphatase (E.C. 3.1.3.11) $(27,28)$, pyruvate carboxylase $(1,8,11,15,16,18,33,37)$, pyruvate dehydrogenase complex (PDC) $(7,13,32,35)$, and PEPCK $(14,17,40)$. With the exception of PDC which catalyzes the first step in the Krebs cycle, the enzymes are necessary for gluconeogenesis in mammalian renal cortex and liver. In addition to its gluconeogenic role pyruvate carboxylase is required for the adequate operation of the Krebs cycle because of its role in the replenishment of four-carbon Krebs cycle intermediates. Both the mitochondrial and cytosolic forms of PEPCK are present in human liver.

Fructose 1,6-bisphosphatase (28) and PDC deficiency (7) have been diagnosed in leukocytes and, although there are references to the presence of pyruvate carboxylase in fibroblasts $(3,11,29)$. no detailed assay has been described. Therefore, routine diagnosis for pyruvate carboxylase and both mitochondrial and cytosolic PEPCK deficiency still requires a liver biopsy. Consequently, the establishment of a diagnosis exposes the patient to the risks of a liver biopsy and precludes genetic studies and prenatal diagnosis of the disease. This report presents methods for the assay of pyruvate carboxylase, citrate synthase, and mitochondrial PEPCK in human lymphocytes and fibroblasts. Methods are given for the very rapid separation of mitochondria from cytosol in human lymphocytes and fibroblasts. Evidence is presented that the pyruvate and inosine diphosphate-dependent $\mathrm{H}^{14} \mathrm{CO}_{3}{ }^{-}$fixation observed is due to the activities of pyruvate carboxylase and mitochondrial PEPCK, respectively. Values are given for activities of pyruvate carboxylase, mitochondrial PEPCK, and citrate synthase in fibroblasts, lymphocytes, and leukocytes for normals and for a patient with hepatic, cerebral, and renal cortical pyruvate carboxylase deficiency $(1,2)$.

\section{MATERIALS AND METHODS}

\section{FIBROBLAST CULTURE}

Human skin fibroblasts obtained with informed consent were grown in Eagle's MEM supplemented with $10 \%$ fetal bovine serum, $1000 \mathrm{U} / \mathrm{ml}$ penicillin $\mathrm{G}$, and $5 \mu \mathrm{g} / \mathrm{ml}$ gentamycin, fed every 2-3 days, and harvested 14 days past confluency for early studies and from 3-5 days past confluency for later studies. The cells were harvested with $0.05 \%$ trypsin and $0.02 \%$ ethylenediamine tetraacetric acid (EDTA), washed in phosphate-buffered saline, the pellet resuspended in 5 volumes $2 \mathrm{M}$ sucrose. $50 \mathrm{mM}$ potassium phosphate buffer, $\mathrm{pH} 7.4$, and $0.5 \mathrm{mM}$ EDTA (Isohashi, Leiter, Utter medium: ILU medium) (20), and frozen at $-76^{\circ}$. Cell scrapings and culture medium were checked for bacterial and mycoplasmal contamination (36). Five to 6 million cells provided enough material to assay for pyruvate carboxylase, PEPCK, and citrate synthase. Immediately before assay, the cells were rapidly thawed and homogenized in a ground glass tube with a ground glass pestle in 6 volumes $25 \mathrm{mM}$ potassium phosphate buffer, $\mathrm{pH}$ 7.4 , and $0.5 \mathrm{mM}$ EDTA for $8-10$ passes at $800 \mathrm{rpm}$ at $4^{\circ}$. The homogenate was lyophilized and the residue was immediately 


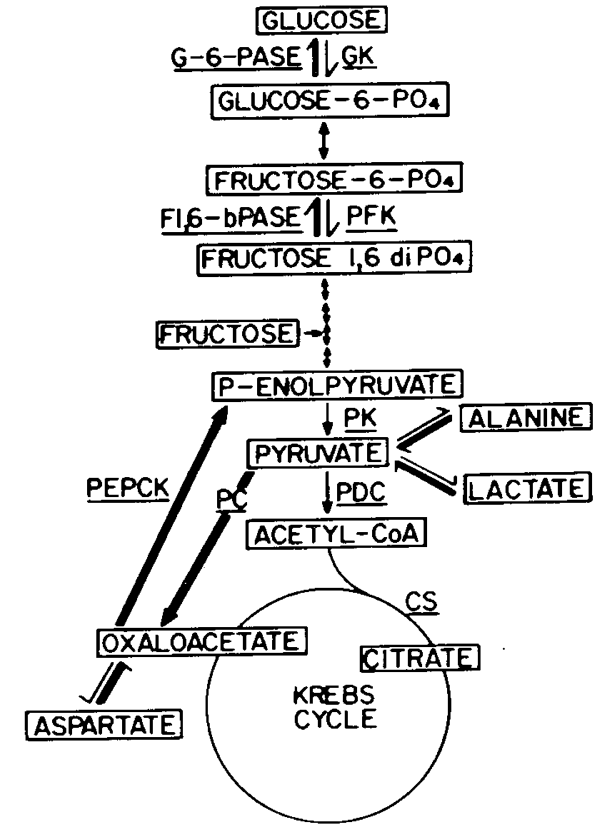

Fig. 1. Pathways of glycolysis, Krebs cycle, and gluconeogenesis in liver. Gluconeogenic pathway is represented by heavy arrows. GK, glucokinase; G-6-pase, glucose 6-phosphatase; PFK, phosphofructokinase; F 1,6-bpase, fructose 1,6-bisphosphatase; PK, pyruvate kinase; PDC, pyruvate dehydrogenase complex; $\mathrm{PC}$, pyruvate carboxylase; $\mathrm{CS}$, citrate synthase; and PEPCK, phosphoenolpyruvate carboxykinase.

taken up in 3.5-7.0 volumes ice-cold $0.1 \mathrm{M}$ sucrose, $25 \mathrm{mM}$ potassium phosphate buffer, $\mathrm{pH} 7.4$, and assayed.

\section{LEUKOCYTE ISOLATION}

Leukocytes were obtained with informed consent and isolated according to a modification of the method of Kampine et al. (21) with erythrocytes lysed by osmotic shock (12). Dextran (Sigma Chemical Co., St. Louis, MO) used in the leukocyte separation had an average molecular weight of 170,000 . The cell pellet was resuspended in 4-5 volumes ILU medium and frozen at $-76^{\circ}$. The yield from $15 \mathrm{ml}$ fresh whole venous blood, 2-5 million mononuclear cells, is adequate for the determination of pyruvate carboxylase, PEPCK, and citrate synthase. Immediately before assay the cells were thawed and homogenized in 6-9 volumes icecold $0.25 \mathrm{M}$ sucrose, $5 \mathrm{mM}$ potassium phosphate buffer, $\mathrm{pH} 7.4$, $0.5 \mathrm{mM}$ EDTA, at $4^{\circ}$ for $8-10$ passes, $800 \mathrm{rpm}$ in a smooth glass tube with a Teflon pestle. The homogenate was freeze-thawed three times in a dry ice-acetone bath and assayed.

\section{LYMPHOCYTE ISOLATION}

Lymphocytes, monocytes, and platelets were isolated from fresh whole venous blood with the use of Ficol-Paque (Pharmacia Fine Chemicals, Piscataway, NJ) density 1.077. The platelets were removed (30), and the lymphocyte and monocyte pellet was resuspended in 4-5 volumes ILU medium and frozen at $-76^{\circ}$. Ten to 15 million cells, easily derived from $15 \mathrm{ml}$ whole venous blood, is sufficient to assay for pyruvate carboxylase, PEPCK, and citrate synthase. Immediately before assay the cells were treated as described above for leukocytes.

\section{ENZYME ASSAYS}

Pyruvate carboxylase was assayed by a modification of the methods of Utter and Keech (38) and Ballard and Hanson (4). The assay included: $45 \mu \mathrm{mol}$ Tris- $\mathrm{HCl}, \mathrm{pH} 7.8 ; 5 \mu \mathrm{mol} \mathrm{MgCl}_{2} ; 2.0$ $\mu \mathrm{mol}$ ATP; $0.33 \mu \mathrm{mol}$ acetyl CoA; $25 \mu \mathrm{mol} \mathrm{NaH}^{14} \mathrm{CO}_{3}{ }^{-}(0.1$ $\mathrm{mCi} / \mathrm{mmol}$, Amersham/Searle, Arlington Heights, IL); $10 \mu \mathrm{mol}$ $\mathrm{Na}$ pyruvate; $2.2 \mathrm{U}$ citrate synthase/ml of assay mix. The leuko- cyte, lymphocyte, or fibroblast homogenate was preincubated for $4 \mathrm{~min}$ in $250 \mu \mathrm{g}$ octyl-phenoxypolyethoxyethanol (Triton X-100, Sigma Chemical Co., St. Louis, MO) per ml assay mix to solubilize the mitochondria and make the pyruvate carboxylase accessible to the assay components. The assay was run in small glass tubes in a total volume of $1 \mathrm{ml}$. A 4-min preincubation at $37^{\circ}$ in the presence of Triton X-100 and all assay ingredients except pyruvate was performed. The reaction was started by the addition of pyruvate (glass-distilled water for the blank), run for the indicated time at $37^{\circ}$, and stopped with $0.5 \mathrm{ml} 10 \%$ trichloroacetic acid. The tubes were centrifuged to remove the protein. The clear supernatant layer was removed and bubbled with $\mathrm{CO}_{2}$ for at least $4 \mathrm{~min}$ to remove radioactive $\mathrm{CO}_{2}$, and $1 \mathrm{ml}$ of the resulting fluid was added to Aqueous Counting Scintillant (ACS, Amersham/Searle) or Formula-963 (New England Nuclear, Boston, MA) and counted in a Packard Tri-Carb scintillation spectrometer (La Grange, IL). Each assay was corrected for even slight fluctuations in the counting efficiency of ${ }^{14} \mathrm{C}$ from day-to-day or machine-to-machine. The assay for PEPCK was as described by Ballard and Hanson (4) with the addition of NADH and malate dehydrogenase to ensure the conversion of the unstable product, oxaloacetate, to malate. The assays were run at $37^{\circ}$ after preincubation for $4 \mathrm{~min}$ with $250 \mu \mathrm{g}$ Triton X-100 per ml assay mix. Adenosine diphosphate was substituted for inosine diphosphate as the blank. Radioactivity was determined as for the pyruvate carboxylase assay. Citrate synthase was assayed at $37^{\circ}$ by a spectrophotometric method which depends on the release of CoA-SH in the presence of 5,5'-dithiobis(2-nitrobenzoate) as described by Isohashi et al. (20). Lactate dehydrogenase (E.C. 1.1.1.27) was assayed as described (22). Protein was determined by the method of Lowry et al. (26).

\section{ISOLATION OF METABOLIC PRODUCTS}

The product of the pyruvate carboxylase reaction in human fibroblasts and lymphocytes was determined by chromatographing the appropriate deproteinated reaction mixture, to which 0.15 $\mu \mathrm{mol}$ nonradioactive citrate was added as carrier, on a Biorad (Richmond, CA) Ag 1-X8 Dowex, 200-400 mesh $\mathrm{Cl}^{-}$anion exchange column (39) and eluting with $30 \mathrm{mM} \mathrm{HCl}$. Fractions were assayed for citrate with citrate lyase (E.C. 4.1.3.6) coupled with malate dehydrogenase followed spectrophotometrically (24) and for radioactivity. The product of the PEPCK reaction in human fibroblasts and leukocytes was determined by chromatographing the appropriate deproteinated reaction mixture, to which $2 \mu \mathrm{mol}$ nonradioactive malate was added as carrier, on a Biorad Ag 1-X8 Dowex, 200-400 mesh, $\mathrm{Cl}^{-}$ion-exchange column. Fractions were assayed for malate (25) and for radioactivity. Radioactive citrate and malate were determined by counting in ACS on a Packard Tri-Carb Liquid scintillation spectrometer.

\section{ISOLATION OF MITOCHONDRIA FROM FIBROBLASTS AND} LYMPHOCYTES

Mitochondria were separated from lymphocytes or fibroblasts by a modification (27) of the method of Zuurendonk and Tager (41) which utilizes the specific attraction of digitonin for cholesterol and the fact that the plasma membrane contains more cholesterol than the mitochondrial membrane (10). Lymphocytes or fibroblasts were harvested as described above, resuspended in ice-cold $0.25 \mathrm{M}$ sucrose, $20 \mathrm{mM}$ potassium morpholinopropane sulfonate, $\mathrm{pH} 7.2,3 \mathrm{mM}$ EDTA, and exposed to digitonin (A grade, Calbiochem, La Jolla, CA), final concentration $1 \mathrm{mg} / \mathrm{ml}$, at $4^{\circ}$ for $60 \mathrm{sec}$, the cells rapidly pelleted with an Eppendorf Micro Centrifuge 3200 (Brinkman Instruments, Inc., Westbury, NY) at $8000 \mathrm{~g}$ for $1 \mathrm{~min}$ at $7^{\circ}$. The supernatant was removed, rapidly frozen in a dry ice-ethanol bath, and stored at $-76^{\circ}$. The mitochondrial pellet was washed twice in the sucrose-morpholinopropane sulfonate-EDTA buffer and the pellet was quick frozen at $-76^{\circ}$. Both fractions were assayed for PEPCK, citrate synthase, and lactic dehydrogenase as described above. 


\section{PREPARATION OF ANTIBODIES TO PYRUVATE CARBOXYLASE}

Purified chicken liver pyruvate carboxylase, judged 95\% pure by sodium dodecyl sulfate polyacrylamide gel electrophoresis, was injected into a goat and the subsequent immunoglobulin $G$ fraction of the antiserum purified by precipitation with $40 \%$ ammonium sulfate followed by chromatography on DEAE cellulose (9). The purified antibody was preincubated with either the bovine lymphocyte or human fibroblast enzyme for $10 \mathrm{~min}$ at $37^{\circ}$ in

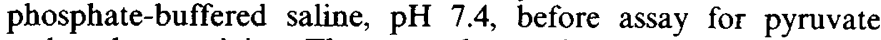
carboxylase activity. The control experiment consisted of the fibroblast or lymphocyte enzyme preincubated with a purified fraction of control goat immunoglobulin $G$ under similar conditions.

\section{RESULTS}

Early experiments demonstrated that greater than $97 \%$ of the PEPCK and pyruvate carboxylase activities were present in the mononuclear (lymphocyte plus monocyte) leukocyte fraction of whole venous blood. Therefore, all results from mixed leukocyte preparations were expressed in terms of milligrams of mononuclear protein to reduce the error caused by variations in the differential white blood count. Pyruvate carboxylase activity in mixed leukocyte preparations is comparable with that in mononuclear leukocyte preparations. However, activities for citrate synthase are not comparable between the two preparations because the granulocytes possess substantial activity of that enzyme.

The assays for pyruvate carboxylase and PEPCK in leukocytes and fibroblasts were linear with time and amount of added protein within the indicated limits (Figs. 2 and 3). Leukocyte PEPCK activity was linear only from $24-90 \mathrm{~min}$ when $100 \mu \mathrm{g}$ total protein was assayed and linear for even shorter times as the total protein was increased further. The assay for pyruvate carboxylase in lymphocytes was linear up to $105 \mathrm{~min}$ when $10-20 \mu \mathrm{g}$ protein was assayed. Good linearity of PEPCK activity was observed in lymphocytes for 45-90 min when $10-20 \mu \mathrm{g}$ protein was assayed.

Ion-exchange chromatography of the reaction products of the pyruvate carboxylase assay in human fibroblasts and peripheral lymphocytes demonstrated that 80 and $100 \%$, respectively, of the radioactive product co-chromatographed with citrate, the major expected reaction product in the presence of citrate synthase. The $20 \%$ unaccounted radioactive product may have been present as

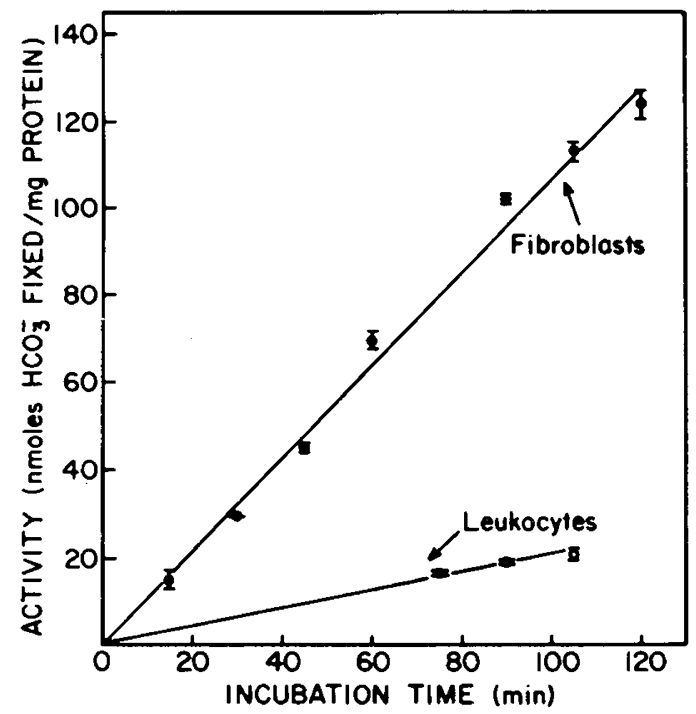

Fig. 2. Linearity of pyruvate carboxylase assay in fibroblasts (๑) and leukocytes $(O)$. Assays are as described under Materials and Methods. The values represent the mean \pm SEM (34) of duplicates from which a blank, corresponding to each time point, was subtracted. The leukocyte assay contained $13.1 \mu \mathrm{g}$ mononuclear protein and $37.5 \mu \mathrm{g}$ total protein. The fibroblast assay contained $37.3 \mu \mathrm{g}$ protein.

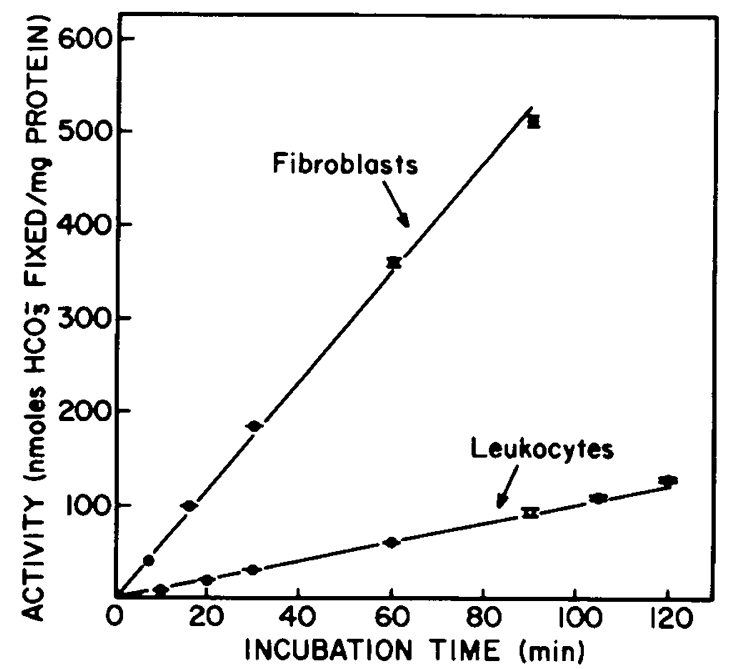

Fig. 3. Linearity of PEPCK assay in fibroblasts (O) and leukocytes (O). Assays are as described under Materials and Methods. The values represent the mean \pm SEM (34) of duplicates from which a blank, corresponding to each time point, was subtracted. The leukocyte assay contained $27.9 \mu \mathrm{g}$ mononuclear protein and $80.0 \mu \mathrm{g}$ total protein. The fibroblast assay contained $47.6 \mu \mathrm{g}$ protein.

isocitrate and cis-aconitate due to the presence of aconitate hydratase in the fibroblasts. Dowex chromatography of the reaction products of the PEPCK assay in human fibroblasts and peripheral leukocytes established that 85 and $75 \%$, respectively, of the fixed radioactivity co-eluted with malate, the major expected product. The 15-25\% nonmalate product may have been fumarate due to the conversion of malate to fumarate by fumarase in the tissues. Incubation of human fibroblasts and bovine lymphocytes with purified goat antibodies to chicken liver pyruvate carboxylase completely inactivated enzyme activity. The control, consisting of fibroblast or lymphocyte enzyme preincubated with purified control goat immunoglobulin fraction produced no inactivation.

The cellular fractionation studies in which citrate synthase and lactic dehydrogenase were used as mitochondrial and cytosolic markers, respectively, demonstrated that all of the PEPCK activity in human lymphocytes and fibroblasts is mitochondrial. Only 8.5 and $3.8 \%$ of the mitochondrial marker enzyme, citrate synthase, was found in the lymphocyte and fibroblast cytosol, respectively. Only 4.1 and $6.7 \%$ of the cytosolic marker enzyme, lactic dehydrogenase, was associated with the lymphocyte and fibroblast mitochondria, respectively (Table 1).

The effect of time from culture confluency to harvest on the activity of the three enzymes is shown in Figure 4. There was no significant change in either pyruvate carboxylase or PEPCK activity although citrate synthase activity doubled from 7-10 days past confluency. A different strain of normal human fibroblasts was harvested 24 and $48 \mathrm{hr}$ after changing the medium to determine whether the time between the last feeding and harvest affected the enzyme activity. Pyruvate carboxylase activity was $1.01 \pm 0.02$ and $0.778 \pm 0.013$, PEPCK activity $6.32 \pm 0.124$ and $5.38 \pm 0.09$, and citrate synthase activity $20.6 \pm 1.05$ and $51.1 \pm$ $9.5 \mathrm{mU} / \mathrm{mg}$ protein 24 and $48 \mathrm{hr}$, respectively, after the last medium change.

Values for pyruvate carboxylase, PEPCK, and citrate synthase activities in lymphocytes, leukocytes, and fibroblasts in normals and a patient with hepatic, renal cortical, and cerebral pyruvate carboxylase deficiency are given in Tables 2 and 3. In the patient, there was no detectable activity in leukocytes $(<0.009 \mathrm{mU} / \mathrm{mg}$ protein), but fibroblasts had about $1.3 \%$ of normal activity with values which were significant but very close to the limits of the assay (Fig. 5). The patient's PEPCK was somewhat reduced in fibroblasts but normal or only slightly reduced in leukocytes. A mixing experiment in which equal parts of a homogenate of the patients fibroblasts and those of a control were mixed and incu- 
Table 1. Cellular distribution of PEPCK, citrate synthase, and lactic dehydrogenase in circulating human lymphocytes and cultured skin fibroblasts

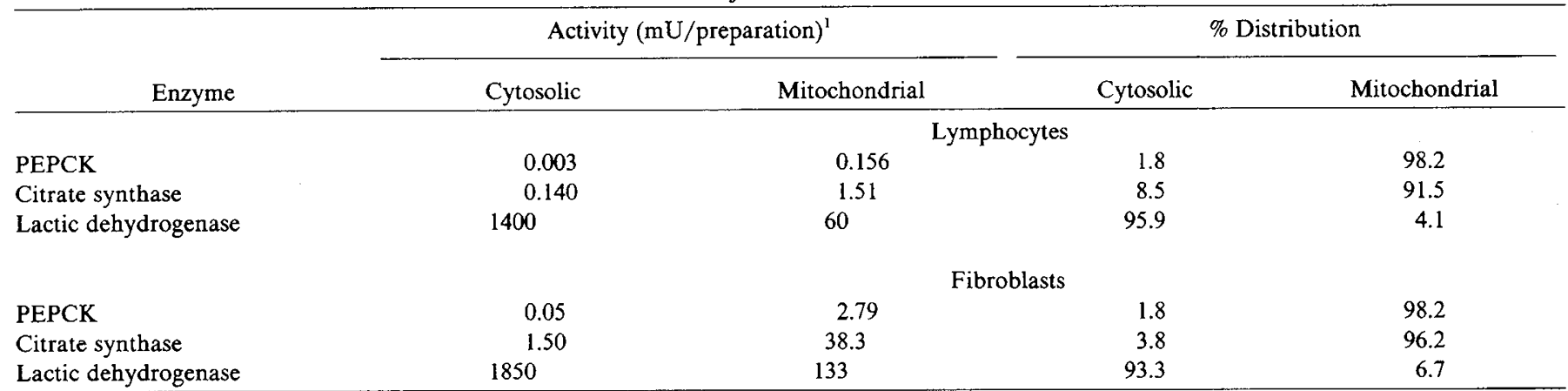

' Milliunits represent for PEPCK: nanomoles of $\mathrm{HCO}_{3}{ }^{-}$fixed per minute; for citrate synthase: nanomoles of CoA-SH produced per minute; and for lactic dehydrogenase: nanomoles of $\mathrm{NAD}^{+}$produced per minute. All assays at $37^{\circ}$. Values represent mean of triplicates for PEPCK and citrate synthase and duplicates for lactic dehydrogenase from which the duplicate or triplicate blank was subtracted. The lymphocyte preparation contained $1.83 \times 10^{7}$ lymphocytes. The fibroblast preparation contained $2.68 \times 10^{6}$ cells.

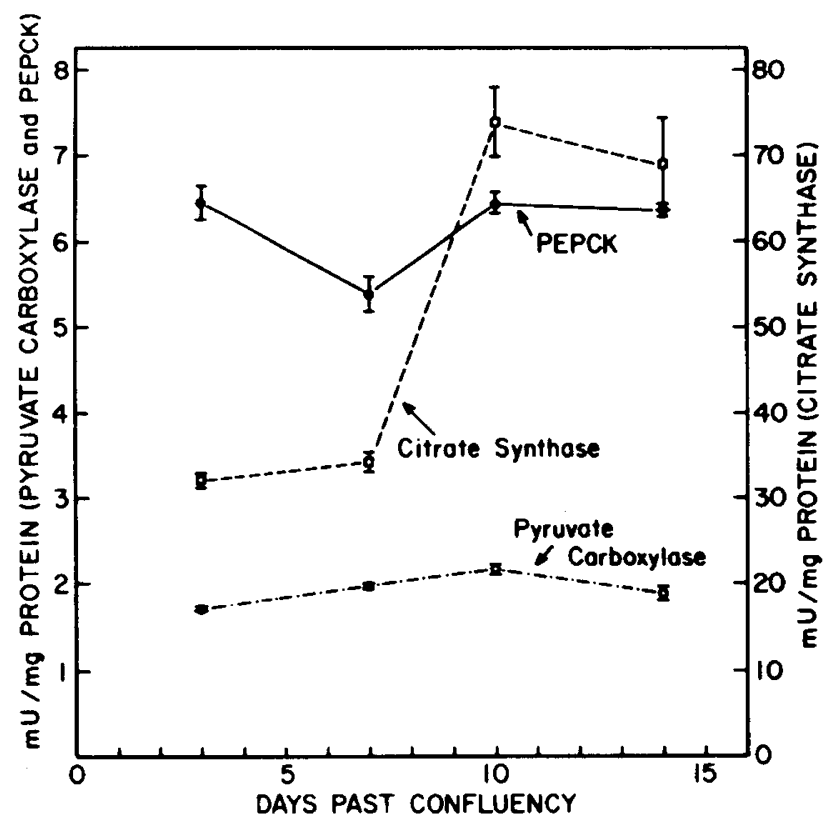

Fig. 4. Effect of days past confluency on pyruvate carboxylase $(O)$, PEPCK (Ө), and citrate synthase $(\square)$ activities. Values and units of activity as described in footnotes 3 and 1 , respectively, Table 2. Assays were performed on an aliquot from 3-4 pooled culture flasks.

bated at $4^{\circ}$ for $25 \mathrm{~min}$ before assay showed no significant activation or inactivation of the control fibroblasts by the patient's fibroblasts. The activity of the mixture was $0.671 \pm 0.017 \mathrm{mU} / \mathrm{mg}$ protein; the expected activity of the mixture was $0.588 \mathrm{mU} / \mathrm{mg}$ protein.

\section{DISCUSSION}

We have recently (1) reported a case of congenital lactic acidosis accompanied by severe mental and developmental retardation and proximal renal tubular acidosis. Although this child had a deficiency of hepatic, renal, and cerebral pyruvate carboxylase (2), there was no evidence of Leigh's disease in the brain at autopsy. The development of the assay for leukocyte and fibroblast pyruvate carboxylase reported here has made it possible to demonstrate that the enzyme was also deficient in the leukocytes and fibroblasts of this child. This finding suggests that it may be possible to diagnose future cases of hepatic pyruvate carboxylase deficiency with lymphocytes or fibroblasts without recourse to liver biopsy. The possible usefulness of fibroblasts to diagnose pyruvate carboxylase deficiency is supported by the finding of DeVivo et al. (11) that a mentally retarded patient with lactic acidosis and hepatic pyruvate carboxylase deficiency had no detectable fibroblast pyruvate carboxylase activity. The generalized pyruvate carboxylase deficiency in the patient presented here provides the strongest evidence to date that only one form of pyruvate carboxylase exists in all human tissues containing the enzyme. That there might be only one form was suggested by the observation of Ballard et al. (5) that an antibody to rat liver pyruvate carboxylase cross-reacted with the enzyme from rat kidney, mammary gland, and white and brown adipose tissue. Consistent with the hypothesis is the fact that the tetramers of all animal pyruvate carboxylases so far examined appear to be composed of subunits identical with respect to molecular weight and biotin content (6). If it is found that all future patients with hepatic pyruvate carboxylase deficiency also have lymphocytes and fibroblasts deficient in pyruvate carboxylase, the validity of the lymphocyte and fibroblast assay for the diagnosis of hepatic pyruvate carboxylase deficiency will be established.

The cellular fractionation studies on lymphocytes and fibroblasts demonstrate that all the PEPCK activity is present in the mitochondrial fraction. The presence of $4-8 \%$ of the citrate synthase activity in the cytoplasm indicates that the $1.8 \%$ of the PEPCK activity found in the cytosol is due to mitochondrial leakage. Contamination of the mitochondria by cytosolic components was very small as indicated by only $4-7 \%$ of the lactic dehydrogenase associated with the mitochondrial fraction. The absence of the cytosolic form of PEPCK in fibroblasts and lymphocytes unfortunately means that a diagnosis of cytosolic PEPCK deficiency (40) will still depend on a liver biopsy. Moreover, until there is evidence, by the observation in several patients with a hepatic mitochondrial PEPCK deficiency concomitant with a fibroblast and lymphocyte mitochondrial PEPCK deficiency, that the mitochondrial form of the enzyme in fibroblasts and lymphocytes is genetically identical to that in human liver, the diagnosis of mitochondrial PEPCK deficiency must also depend on a liver biopsy. The significantly reduced activity of PEPCK in the patient's fibroblasts (Table 3 ) remains to be explained. The activity in leukocytes (Table 2) may not represent a significant decrease. It is possible that the very low levels of pyruvate carboxylase in the patient's tissues resulted in a reduced activity and/or synthesis of PEPCK. However, the mechanism by which this might occur is not known. A more likely explanation lies in the fact that all of the assay requirements necessary for maximum activity of mammalian mitochondrial PEPCK may not be known. The absence or presence of a trace metal, for example, in some homogenates but not in others could account for the variation of activities observed.

For the assays for both pyruvate carboxylase and PEPCK to be valid, it is of the utmost importance to adjust the incubation time and amount of protein used in each assay in order to remain on 
Table 2. Pyruvate carboxylase, PEPCK, and citrate synthase activities in leukocytes and lymphocytes of normal humans and a patient with pyruvate carboxylase deficiency

\begin{tabular}{lccc}
\hline Subject & $\begin{array}{c}\text { Pyruvate carboxylase } \\
(\mathrm{mU} / \mathrm{mg} \text { protein })^{1}\end{array}$ & $\begin{array}{c}\text { PEPCK } \\
(\mathrm{mU} / \mathrm{mg} \text { protein })^{1}\end{array}$ & $\begin{array}{c}\text { Citrate synthase } \\
(\mathrm{mU} / \mathrm{mg} \text { protein })^{1}\end{array}$ \\
\hline & & - & - \\
Children & $0.089 \pm 0.005(n=2)^{3}$ & Mixed peripheral leukocytes $^{2}$ & \\
& $(0.084,0.094)$ & $1.68 \pm 0.038(n=2)$ & $302 \pm 13.8(1)(n=1)$ \\
Adults & $0.095 \pm 0.014(n=3)$ & $(1.64,1.72)$ & $47.6 \pm 0.841(1)$ \\
& $(0.070-0.208)$ & $0.930 \pm 0.130(1)$ & $66.5 \pm 6.28(n=5)$ \\
Patient & $0.009(2)$ & Circulating lymphocytes $^{2}$ & \\
& & $1.42 \pm 0.119(n=5)$ & $(46.3-95.7)$ \\
Adults & $0.154 \pm 0.028(n=5)$ & $(0.824-1.88)$ & \\
& $(0.092-0.262)$ & & \\
\hline
\end{tabular}

\footnotetext{
' Milliunits of pyruvate carboxylase and PEPCK represent nanomoles of $\mathrm{HCO}_{3}{ }^{-}$fixed per minute per milligram of protein at $37^{\circ}$; milliunits of citrate synthase represent nanomoles of CoA-SH produced per minute per milligram of protein at $37^{\circ}$. Milligrams of protein for both mixed peripheral leukocytes and circulating lymphocytes represent milligrams of lymphocyte plus monocyte protein.

${ }^{2}$ Blood samples from all subjects were drawn at 3:30-4:00 PM when the individuals were from 3-4 hr postprandial.

${ }^{3}$ Values are expressed as the mean \pm SEM (34) followed by the range and the number of control subjects $(n)$ or the number of separate assays ( ) on the same tissue. If a subject was only assayed once, the value represents the mean \pm SEM of the replicate determinations (two to three for citrate synthase, six for pyruvate carboxylase and PEPCK in lymphocytes or leukocytes, and four for pyruvate carboxylase and PEPCK in fibroblasts) from which the blank was subtracted.
}

Table 3. Pyruvate carboxylase, PEPCK, and citrate synthase activities in fibroblasts of normal humans and a patient with pyruvate carboxylase deficiency

\begin{tabular}{|c|c|c|c|}
\hline Subject & $\begin{array}{l}\text { Pyruvate carboxylase } \\
(\mathrm{mU} / \mathrm{mg} \text { protein })^{1}\end{array}$ & $\begin{array}{c}\text { PEPCK } \\
(\mathrm{mU} / \mathrm{mg} \text { protein })^{1}\end{array}$ & $\begin{array}{c}\text { Citrate synthase } \\
(\mathrm{mU} / \mathrm{mg} \text { protein })^{1}\end{array}$ \\
\hline TC 5: 12 mo, patient ${ }^{2}$ & $\begin{array}{l}0.018 \pm 0.001(4) \\
(0.016-0.021)\end{array}$ & $\begin{array}{l}0.954 \pm 0.134(2) \\
(0.820,1.09)\end{array}$ & $\begin{array}{l}28.9 \pm 2.22(4) \\
(25.6-35.2)\end{array}$ \\
\hline TC 48: <3 days, normal & $\begin{array}{l}1.95 \pm 0.096(4) \\
(1.73-2.19)\end{array}$ & $\begin{array}{l}6.13 \pm 0.109(5) \\
(5.38-6.43)\end{array}$ & $\begin{array}{l}52.3 \pm 11.1(4) \\
(32.2-73.7)\end{array}$ \\
\hline ST 12: adult, normal & $0.95 \pm 0.069$ & - & - \\
\hline RK: adult, normal & $1.23 \pm 0.040(5)$ & - & - \\
\hline TC 60: adult, normal & - & $3.94 \pm 0.052(1)$ & $16.3 \pm 1.10(1)$ \\
\hline TC 61: adult, normal & - & $\begin{array}{l}6.33 \pm 0.33(2) \\
(6.00,6.66)\end{array}$ & $18.4 \pm 3.10(1)$ \\
\hline TC 73: adult, normal & - & $5.94 \pm 0.061(1)$ & $20.9 \pm 3.10(1)$ \\
\hline
\end{tabular}

${ }^{1}$ Milliunits of enzyme activity and values are as described in the legend of Table 1.

${ }^{2}$ Culture number of each fibroblast line is followed by the age of the donor at biopsy and the clinical condition of the donor.

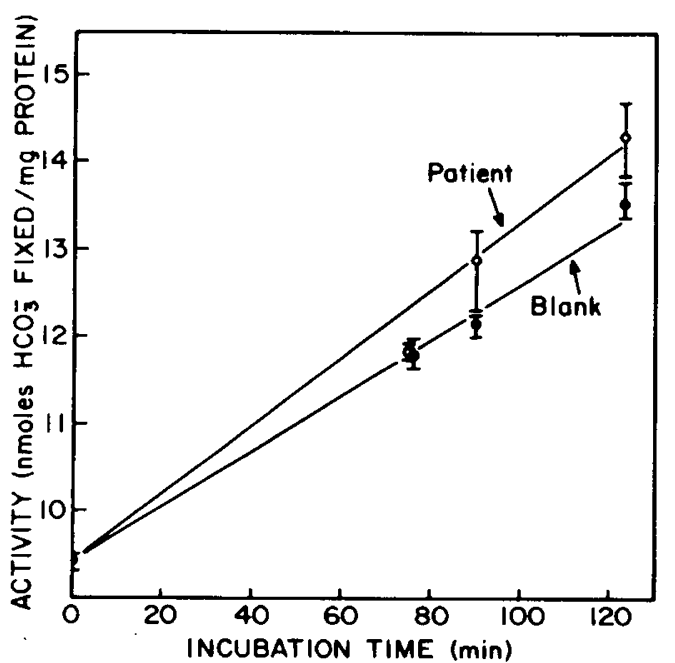

Fig. 5. Pyruvate carboxylase activity in the patient's fibroblasts. The assay was as described under Materials and Methods. Each value represents the mean \pm SEM (34) of triplicate values. the linear portion of the assay curve. This is especially important with the PEPCK assay in fibroblasts. The experiments on the effect of days past confluency to harvest on PEPCK and pyruvate carboxylase activity (Fig. 4) demonstrate that there is no effect on activity from 3-14 days past confluency. The time of harvesting with respect to the last medium change has no significant effect on pyruvate carboxylase or PEPCK. However, there is an apparent effect on citrate synthase both with respect to days past confluency and time after the last medium change. The great variability in the citrate synthase activity observed throughout this study (Tables 2 and 3 ) indicates that this enzyme, while useful as a qualitative mitochondrial marker enzyme, is not useful in these tissues as a quantitative reference enzyme to which other enzyme activities can be compared. Our finding that there was no change in pyruvate carboxylase or PEPCK activity from 3-14 days past confluency (8-20 days after subculture, respectively) is in agreement with the finding of Raghunathan et al. (31). They, however, observed a larger variation in the activities of PEPCK and pyruvate carboxylase in fibroblasts than we and suggested that this could be an indication of genetic polymorphism in the case of pyruvate carboxylase. Although we did not examine as many fibroblast lines as Raghunathan et al., we found no evidence for 
genetic polymorphism of either pyruvate carboxylase or PEPCK in either fibroblasts or lymphocytes.

\section{REFERENCES AND NOTES}

1. Atkin, B., Buist, N., Leiter, A., and Utter, M.: CRM-positive hepatic pyruvate carboxylase deficiency associated with renal tubular acidosis (RTA). Am. J. Hum. Genet., 27: 14A (1975).

2. Atkin, B. M., Buist, N. R. M., Utter, M. F., Leiter, A. B., and Banker, B. Q.: Pyruvate carboxylase deficiency and lactic acidosis in a retarded child without Leigh's syndrome. Pediatr. Res. (In press.)

3. Atkin, B. M., Utter, M. F., Weinberg, M. B., and Buist, N. R. M.: Detection of pyruvate carboxylase deficiency in leukocytes and fibroblasts. Pediatr. Res., 11: 452 (1977).

4. Ballard, F. J., and Hanson, R. W.: Phosphoenolpyruvate carboxykinase and pyruvate carboxylase in developing rat liver. Biochem. J., 104: 866 (1967).

5. Ballard, F. J., Hanson, R. W., and Reshef, L.: Immunochemical studies with soluble and mitochondrial pyruvate carboxylase activities from rat tissues. Biochem. J., 119: 735 (1970).

6. Barden, R. E., Taylor, B. L., Isohashi, F., Frey, W. H., II, Zander, G., Lee, J. C., and Utter, M. F.: Structural properties of pyruvate carboxylases from chicken liver and other sources. Proc. Natl. Acad. Sci. U.S.A., 72: 4308 (1975).

7. Blass, J. P., Avigan, J., and Uhlendorf, B. W.: A defect in pyruvate decarboxylase in a child with an intermittent movement disorder. J. Clin. Invest., 49: 423 (1970).

8. Brunette, M. G., Delvin, E., Hazel, B., and Scriver, C. R.: Thiamin-responsive lactic acidosis in a patient with a deficient low- $K_{m}$ pyruvate carboxylase activity in liver. Pediatrics, 50: 702 (1972).

9. Campbell, D. H., Garvey, J. S., Cremer, N. E., and Sussdorf, D. H. (eds): Methods of Immunology, 2nd Ed., pp. 183-209 (W. A. Benjamin, Inc., New York, 1970).

10. Colbeau, A., Nachbaur, J., and Vignais, P. M.: Enzymic characterization and lipid composition of rat liver subcellular membranes. Biochim. Biophys. Acta. 249: 462 (1971)

11. DeVivo, D C. Haymond, M. W., Leckie, M. P., Bussmann, Y. L., McDougal, D. B., Jr., and Pagliara, A. S.: The clinical and biochemical implications of pyruvate carboxylase deficiency. J. Clin. Endocrinol. Metab. 45: 1281 (1977)

12. Fallon, H. J., Frei, E., III, Davidson, J. D., Trier, J. S., and Burk, D.: Leukocyte preparations from human blood: evaluation of their morphologic and metabolic state. J. Lab. Clin. Med., 59: 779 (1962).

13. Farrell, D. F., Clark, A. F., Scott, C. R., and Wennberg, R. P.: Absence of pyruvate decarboxylase activity in man: A cause of congenital lactic acidosis. Science (Wash., D. C.), 187: 1082 (1975).

14. Fiser, R. H., Jr., Melsher, H. L., and Fisher, D. A. Hepatic phosphoenol pyruvate carboxylase (PEPCK) deficiency. A new cause of hypoglycemia in childhood. Pediatr. Res., 10: 60 (1974).

15. Grover, W. D., Auerbach, V. H., and Patel, M. S.: Biochemical studies and therapy in subacute necrotizing encephalomyelopathy (Leigh's syndrome). J. Pediatr., 81: 39 (1972).

16. Gruskin, A. B., Patel, M. S., Linshaw, M., Ettenger, R., Huff, D., and Grover, W.: Renal function studies and kidney pyruvate carboxylase in subacute necrotizing encephalomyelopathy (Leigh's syndrome). Pediatr. Res., 7: 832 (1973).

17. Hommes, F. A., Bendien, K., Elema, J. D., Bremer, H. J., and Lombeck, I.: Two cases of phosphoenolpyruvate carboxykinase deficiency. Acta Paediatr. Scand. 65: 233 (1976).

18. Hommes, F. A., Polman, H. A., and Reerink, J. D.: Leigh's encephalomyelopathy: An inborn error of gluconeogenesis. Arch. Dis. Child., 43: 423 (1968)

19. Howell, R. R., Ashton, D. M., and Wyngaarden, J. B.: Glucose 6-phosphatase deficiency glycogen storage disease. Studies on the interrelationships of carbohydrate lipid, and purine abnormalities. Pediatrics, 29: 553 (1962).

20. Isohashi, F., Leiter, A., Weinberg, M., Utter, M. F., and Murphy, J. (Unpublished observations.)

21. Kampine, J. P., Brady, R. O., Kanfer, J. N., Feld, M., and Shapiro, D.: Diagnosis of Gaucher's disease and Niemann-Pick disease with small samples of venous blood. Science (Wash., D. C.), 155: 86 (1966).
22. Kornberg, A.: Lactic dehydrogenase of muscle. In: S. P. Colowick, and N. O. Kaplan: Methods of Enzymology, Vol. I, p. 441 (Academic Press, New York, 1955).

23. Lowe, C. U., Sokal, J. E., Mosovich, L. L., Sarcione, E. J., and Doray, B. H.: Studies in liver glycogen disease. Effects of glucagon and other agents on metabolic pattern and clinical status. Am. J. Med., 33: 4 (1962).

24. Lowry, O. H., and Passonneau, J. V.: A Flexible System of Enzymatic Analysis, p. 157 (Academic Press, New York, 1972).

25. Lowry, O. H., and Passonneau, J. V.: A Flexible System of Enzymatic Analysis p. 201 (Academic Press, New York, 1972).

26. Lowry, O. H., Rosebrough, N. J., Farr, A. L., and Randall, R. J.: Protein measurements with the folin phenol reagent. J. Biol. Chem., 193: 265 (1951)

27. Mackall, J. C., and Lane, D.: Role of pyruvate carboxylase in fatty acid synthesis: Alterations during preadipocyte differentiation. Biochem. Biophys. Res. Commun., 79: 720 (1977).

28. Melancon, S. B., Khachadurian, A. K., Nadler, H. L., and Brown, B. I.: Metabolic and biochemical studies in fructose 1,6-diphosphatase deficiency. J. Pediatr. 82: 650 (1973)

29. Pagliara, A. S., Karl, I. E., Keating, J. P., Brown, B. I., and Kipnis, D. M.: Hepatic fructose 1,6-diphosphatase deficiency. J. Clin. Invest., 51:2115 (1972).

30. Perper, R. J., Zee, T. W., and Mickelson, M. M.: Purification of lymphocytes and platelets by gradient centrifugation. J. Lab. Clin. Med., 72: 842 (1968).

31. Raghunathan, R. Russell, J. D., and Arinze, I. J.: Pyruvate carboxylase and phosphoenolpyruvate carboxykinase in cultured human fibroblasts. J. Cell. Physiol., 92: 285 (1977).

32. Robinson, B. H., and Sherwood, W. G.: Pyruvate dehydrogenase phosphatase deficiency: A cause of congenital chronic lactic acidosis in infancy. Pediatr. Res., 9: 935 (1975).

33. Saudubray, J. M., Marsac, C., Charpentier, C., Cathelineau, L., Besson Leaud, M., and Leroux, J. P.: Neonatal congenital lactic acidosis with pyruvate carboxylase deficiency in two siblings. Acta Paediatr. Scand., 65: 717 (1976).

34. Snedecor, G. W., and Cochran, W. G.: Statistical Methods, 6th Ed. (Iowa State University Press, Ames, Iowa 1967).

35. Stromme, J. H., Borud, O., and Moe, P. J.: Fatal lactic acidosis in a newborn attributable to a congenital defect of pyruvate dehydrogenase. Pediatr. Res. 10: 60 (1976).

36. Studzinski, G. P., Gierthy, J. F., and Chon, J. J.: An autographic screening test for mycoplasmal contamination of mammalian cell culture. In Vitro, 8: 466 (1973).

37. Tang, T. T., Good, T. A., Dyken, P. R., Johnsen, S. D., McCreadie, S. R., Sy, S T., Lardy, H. A., and Rudolph, F. B.: Pathogenesis of Leigh's encephalomyelopathy. J. Pediatr., 81: 189 (1972).

38. Utter, M. F., and Keech, D. B.: Pyruvate carboxylase I. Nature of the reaction. J. Biol Chem., 238: 2603 (1963)

39. Van Korff, R. W.: Ion-exchange chromatography of citric acid cycle components and related compounds. In: S. P. Colowick, and N. O. Kaplan: Methods of Enzymology, Vol. XIII, p. 425 (Academic Press, New York, 1969).

40. Vidnes, J., and Søvik, O.: Gluconeogenesis in infancy and childhood. III Deficiency of the extramitochondrial form of hepatic phosphoenolpyruvate carboxykinase in a case of persistent neonatal hypoglycaemia. Acta Paediatr. Scand., 65: 307 (1976).

41. Zuurendonk, P. F., and Tager, J. M.: Rapid separation of particulate components and soluble cytoplasm of isolated rat liver cells. Biochim. Biophys. Acta, 333 393 (1974).

42. The authors thank Drs. Robert D. Koler and Neil R. M. Buist for their support and criticism of this study. They are grateful to Drs. F. Isohashi and Andrew B. Leiter for their preparation of the purified antibodies to chicken liver pyruvate carboxylase. They thank Helen Curtis and Michael Wolpert for their assistance with the tissue culture.

43. This research was supported by NIH Grants HD-00165 and AM-12245, grants from the National Foundation-March of Dimes C-195, and a National Foundation-March of Dimes Starter Grant to M. F. Utter.

44. Requests for reprints should be addressed to: Beth M. Atkin, Ph.D., Department of Biochemistry, School of Medicine, Case Western Reserve University, Cleveland, $\mathrm{OH} 44106$ (USA).

45. Received for publication December 20, 1977.

46. Accepted for publication March 2, 1978. 